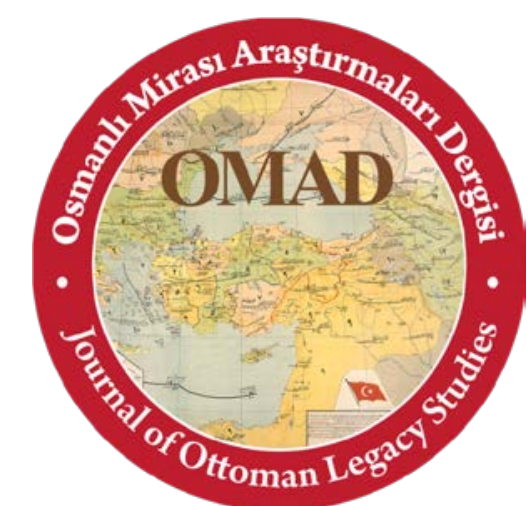

Osmanlı Mirası Araştırmaları Dergisi/Journal of Ottoman Legacy Studies

ISSN 2148-5704

www.osmanlimirasi.net

osmanlimirasi@gmail.com

Cilt 6, Sayı 15, Temmuz 2019 / Volume 6, Issue 15, July 2019

\title{
TEACHING TURKISH GRAMMAR AND SPEAKING TO GERMANS IN GERMANY AROUND 1890S: TÜRKİSCHE KONVERSATIONS- GRAMMATIKK COURSEBOOK
}

1890'larda Almanya'da Almanlara Türkçe Dil Bilgisi ve Konuşma Öğretimi: Türkische Konversations-Grammatik Kitabı

\author{
Makale Türü/Article Types : Araştırma Makalesi/Research Article \\ Geliş Tarihi/Received Date : 29.06.2019 \\ Kabul Tarihi/Accepted Date : 26.07.2019 \\ Sayfa/Pages : 287-295 \\ DOI Numaras1/DOI Number : http://dx.doi.org/10.17822/omad.2019.125
}

\section{ERSOY TOPUZKANAMIŞ}

(Arş. Gör. Dr.), Balıkesir Üniversitesi, Necatibey Eğitim Fakültesi, Türkçe ve Sosyal Bilimler Eğitimi Bölümü, Türkçe Eğitimi Ana Bilim Dalı, Balıkesir / Türkiye, e-mail: ersoytopuzkanamis@gmail.com, ORCID: https://orcid.org/0000-0002-0997-6013

\section{Atıf/Citation}

Topuzkanamıs, Ersoy, “Teaching Turkish Grammar and Speaking to Germans in Germany around 1890s: Türkische Konversations-Grammatik Coursebook", Osmanlı Mirası Araştırmaları Dergisi [Journal of Ottoman Legacy Studies], 6/15, 2019, 287-295. 



\title{
TEACHING TURKISH GRAMMAR AND SPEAKING TO GERMANS IN GERMANY AROUND 1890S: TÜRKISCHE KONVERSATIONS-GRAMMATIK COURSEBOOK*
}

\author{
1890’larda Almanya'da Almanlara Türkçe Dil Bilgisi ve Konuşma Öğretimi: Türkische \\ Konversations-Grammatik Kitabi**
}

\section{ERSOY TOPUZKANAMIŞ}

\begin{abstract}
Understanding the history of teaching Turkish as a foreign language is important to explore methods, techniques, and materials used in the historical process and the way Turkish grammar was depicted. For this reason, coursebooks are the fundamental sources to be investigated. This study aims to investigate Türkische Konversations-Grammatik book written by Heinrich Jehlitschka who was born in Vienna in 1861. The research adopted document analysis method, and 1895 and 1897 editions of the book which comprised of two volumes were utilized. Following the introduction of available author information, the contents of the book was presented in turn. The first volume of the book was organized in two sections; first of which included Turkish elements, and the second section contained Arabic and Persian components. The second volume, on the other hand, served as an answer key, including translations of the texts in the first volume and some detailed information about official correspondence. It is intriguing that, in the first volume, the author offered example texts and translation exercises for each grammar topic. To add, the book focused on developing writing and reading skills. The book is significant since it reflects the Turkish language of the time period in terms of the grammar topics chosen by the author.
\end{abstract}

Keywords: Teaching Turkish to foreigners, Heinrich Jehlitschka, Türkische Konversations-Grammatik, grammar, speaking

Öz: Yabancılara Türkçe öğretimi tarihinin anlaşılması hem tarihsel süreçte kullanılan yöntem, teknik ve materyaller hem de Türkçenin gramerinin nasıl betimlendiğinin görülmesi açısından önem taşımaktadır. Bunun için, ders kitapları öncelikle incelenmesi gereken kaynaklardır. Bu çalışmanın amacı, 1861'de Viyana'da doğan Heinrich Jehlitschka tarafından yazılan Türkische Konversations-Grammatik adlı kitabını incelemektir. Doküman incelemesi yönteminin kullanıldığı çalışmada iki ciltlik eserin 1895 ve 1897 yılındaki basımları değerlendirilmiştir. Yazıda yazar hakkında ulaşılabilen bilgiler verildikten sonra kitabın içeriği sırasıyla tanıtılarak ele alınmıştır. Kitabın birinci cildi ilki Türkçe, ikincisi Arapça ve Farsça ögelerin işlendiği iki bölüm hâlinde düzenlenmiştir. İkinci cilt ise bir yanıt anahtarı olarak düzenlenerek ilk ciltteki metinlerin çevirileri ile resmî yazışmalar konusunda bazı ayrıntılı bilgilere yer verilmiştir. Yazarın ilk ciltteki her bir dil bilgisi konusuyla ilgili örnek metinlerle çeviri alıştırmaları koyması dikkat çekmektedir. Bunun yanında yazma ve okuma becerilerinin gelişmesini hedeflediği de görülmektedir. Kitap, yazarın işlediği dil bilgisi konularının o dönemin Türkçesini yansıtması bakımından önemlidir.

Anahtar Kelimeler: Yabancılara Türkçe öğretimi, Heinrich Jehlitschka, Türkische KonversationsGrammatik, dil bilgisi, konuşma

\section{Introduction}

The history of the interest shown to Turkish language in Europe dates quite a way back. It can be easily stated that the interest of Europeans, who wanted to establish relations with the Ottoman Empire in various ways, increased over the centuries. In this context, numerous

\footnotetext{
* This study was presented at the "Poland and Turkic World International Conference" held on 13-14 May 2019 in Krakow.

** Bu çalışma 13-14 Mayıs 2019 tarihlerinde Krakow'da düzenlenen "Polonya ve Türk Dünyası Uluslararas1 Konferansı"nda sunulmuştur.
} 
schools of orientalism and centers for teaching Turkish were founded in different European cities. These institutions not only aimed to inform the public about orientalism or Ottoman language and culture, but also to train civil servants to deploy to Ottoman provinces or the east. ${ }^{1}$ Although these schools initially led instruction with coursebook written by the Turkish authors, ${ }^{2}$ in time, they started to use coursebooks prepared by the individuals trained or taught within these institutions. ${ }^{3}$ One of the books that fits this description is Türkische KonversationsGrammatik manuscript written by Heinrich Jehlitschka who graduated from the Orientalische Akademie and started working there. This study, therefore, covers the investigation of the aforementioned manuscript.

\section{The Author}

Henry or Heinrich Jehlitschka was born in $26^{\text {th }}$ April 1861 in Vienna. He studied in Orientalische Akademie between 1881-1886. Following his graduation from the institution, he started to work in German external affairs. Till the year of 1914 when he retired, he had worked as consul in places like Shkodra, Alexandria, Cairo, Jerusalem, Prizren, Skopje, Mumbai, Tokyo, Balochistan, Baghdat, Jaffa, Ioannina, Bitola, Sydney, and Thessaloniki. Settling down in Vienna between 1895-1897, he worked as a language teacher in Orientalische Akademie. ${ }^{4}$ In Heidelberg, he published his Türkische Konversations-Grammatik book in 1895 and his Schlüssel zur Türkische Konversations-Grammatik book in 1897. No information is found in the prior research in regards to when he passed away or if he had published any other books in addition to the aforementioned ones.

\section{General Introduction}

The work under investigation whose first volume in 1895 was named Türkische Konversations-Grammatik and second one in 1897 was Schlüssel zur Türkische KonversationsGrammatik is one of the first Turkish grammar books to have ever been written in German. In this sense, it set an example for grammar books published in Europe, and it was especially used as a coursebook for Ottoman Turkish as a foreign language. For instance, Fehim Bayraktareviç stated that he took Jehlitschka's books as reference while authoring his work Osnovi Turske Gramatike (Principles of Turkish Grammar), which was published in Belgrade in 1962. It is also

\footnotetext{
${ }^{1}$ Frédérich Hitzel, Dil Oğlanları ve Tercümanlar, Yapı Kredi Yayınları, İstanbul 1995; Güner Doğan, "Venedik Şark Dil Okulu", Toplumsal Tarih, Volume: 247, 2014, s. 58-63; Ömer Gezer, "Viyana Şark Dilleri Akademisi", Toplumsal Tarih, Volume: 247, 2014, s. 64-72; Özlem Akay Dinç, "Polonya Kralı Poniatowski'nin Diplomasi Reformu Çerçevesinde İstanbul Şarkiyat Mektebi, Toplumsal Tarih, Volume: 247, 2014, s. 86-92; Christoph Herzog, "Almanca Konuşulan Ülkelerde Türkiyat ve Şarkiyat Çalışmalarının Gelişimi Üzerine Notlar” tra. Faruk Yaslıçimen, Türkiye Araştırmaları Literatür Dergisi, Volume: 15, 2010, s. 77-148.

${ }^{2}$ For details, see Güner Doğan, ibid.

${ }^{3}$ For some examples, see Şerife Ünver, "Alman Askerlerine Türkçeyi Öğretme ve Türkiye'yi Tanıtma Amacıyla Yazılan Bir Kitabın İncelenmesi” Milli Folklor, Volume: 25, 2013, 189-201; Ersoy Topuzkanamış, 1915’te İstanbul Alman Okulunda Yabancılara Türkçe Öğretimi: Türkisches Lesebuch Für Deutsche Kitabı, I. Kaşgarlı Mahmud Yabancı Dil Olarak Türkçe Öğretimi Sempozyumu, Erciyes Üniversitesi Kaşgarlı Mahmud Türkçe Öğretim Araştırma-Uygulama Merkezi, 03-05 Mayıs 2018, Kayseri; Ersoy Topuzkanamış, Almanya'da 1. Dünya Savaşı'nda Alman Askerlerine Türkçe Öğretimi: Türkisch Für Offiziere Und Mannschaften Adlı Kitap, Uluslararası Türk Kültürü ve Medeniyeti Kongresi 05-08 Eylül 2018, Balıkesir; Semran Cengiz, "Alman Şarkiyatçı Paul Horn ve Geschichte der Türkischen Moderne (Yeni Türk Edebiyatı Tarihi) Adlı Eseri”. Turkish Studies, Volume: 5(2), 2010, s. 1448-1454; Semran Cengiz, “Alman Kaynaklarında Yeni Türk Edebiyatı. Otto Hachtmann ve 'Die Türkische Literatur des Zwanzigsten Jahrhunderts' Adlı Eseri” Türkbilig/Türkoloji Araştırmaları Dergisi, Volume:11(19), 2010, s. 96-103; Süheyla Doğan, XIX. Yüzyılda Batı'da Yabancılara Türkçe Öğretimi Çalışmaları - W. B. Barker Örneği. Unpublished Master's Thesis, Firat Üniversitesi, Elâzı̆̆ 2010, Halil Ersoylu, “Türk Dili Üzerine Yazılmış İngilizce Gramerler”, Türk Dünyası Araştırmaları, Volume: 10, 1981, s. 114-142.

4 For more information on the author, see Gülcan Yeşilöz, Die Übungstexte in der türkischen Konversationsgrammatik von H. Jehlitschka, Diplomarbeit, Universität Wien, Wien 2013; Rudolf Agstner, Handbuch des k.k. / k.u.k. Konsulardienstes Die Konsulate der Donaumonarchie vom 18. Jh. Bis 1918, Aus dem Nachlass herausgegebenen von Gerhard Gonsa, New Academic Press, Wien 2018; Deusch Engelbert, Die effektiven Konsuln Österreich (-Ungars) von 1825-1918 Ihre Ausbildung, Arbeitsverhältnisse und biografien, Böhlau, Wien 2017, https://www.oapen.org/download?type=document\&docid=645108.
} 
stated that the book was first adapted to Russian and then translated. The transcription of Turkish practice texts containing Arabic letters was published by Helmling under the name "Türkische Konversations-grammatik Umschreibung der türkischen Übungsstücke in Lateinschrift" in 1916. ${ }^{5}$ After deeming Jehlitschka's book to be valuable and important in his review about the book in 1899, Maximillian Bittner proposed that the book skipped proofreading before its publication and offered a list indicating the mistakes in the book. ${ }^{6}$ Indeed, the book contains many mistakes thought to be due to carelessness concerning the parts with both Arabic and Latin letters.

Jehlitschka started the first volume of the book with a preface complaining that even though Ottoman language had been a part of many studies due to its influence in Europe, the gap in this area of teaching it as a foreign language had not been filled properly because Turkish teaching coursebooks published till the time had solely focused on grammar; therefore, he provided various reading texts and exercises in addition to that. For this reason, Jehlitschka proclaimed that Arabic and Persian components were used quite often in Ottoman written language just as Turkish elements were frequent in spoken language; thus, this situation had to be taken into consideration in a coursebook. In the preface, he suggested that Gaspey-OttoSauer method was a plausible method for this; therefore, he decided to divide the book into two chapters in a way that the first chapter included a spoken language in which Turkish was dominant while in the second chapter offered a written language on where Arabic and Persian were superior.

\section{Content and Method}

The first volume comprising of 420 pages consisted the following sections:

Introduction, the alphabet, ebced, introduction of letters, vowel points in Arabic, vowel points in Turkish, pronunciation, writing, similarly written and approximating letters (pp.1-20).

$1^{\text {st }}$ Lesson (pp. 21-24): Articles, gender in nouns, adjectives, -DIr (am, is, are) and değil (not).

$2^{\text {nd }}$ Lesson (pp. 24-29): Plurality in nouns, the attributive and descriptive adjectives, interrogative particle, var (there is/are) and yok (there isn't/aren't) words.

$3^{\text {rd }}$ Lesson (pp. 30-39): Possessive suffixes and adding them to nouns and adverbs.

$4^{\text {th }}$ Lesson (pp. 39-55): Case suffixes.

$5^{\text {th }}$ Lesson (pp. 55-64): Prepositions, conjunctions, gradation in adverbs, reinforcing adjectives, comparative and superlative adjectives, time adverbs, $i$ - verb with nouns, izafet (noun phrase) in Persian.

$6^{\text {th }}$ Lesson (pp. 64-74): Functions of ablative suffix, the use of dative suffix with prepositions and nouns, $k i$ pronoun, adjective making $k i$, ise and variations, the use of var (there is/are) and yok (there isn't/aren't) words, iken (while).

$7^{\text {th }}$ Lesson (pp. 74-82): Various prepositions used in Turkish.

$8^{\text {th }}$ Lesson (pp. 82-89): - lI, sIz, CA, lIk, DAş, CIk suffixes and hendiadys made with m-.

$9^{\text {th }}$ Lesson (pp. 89-97): Nouns deriving from pronouns, compound sentences with $k i, k i$ pronoun, adjective-making $k$, indefinite adjectives, indefinite pronouns.

$10^{\text {th }}$ Lesson (pp. 97-106): Numbers, number groups, numeral adjectives.

\footnotetext{
5 İsmail Eren, “Türkiye Türkçesine Dair Rusça Neşriyat (1176-1963) Üzerinde Bibliyografya Denemesi”, Türkiyat Mecmuasl, Volume: 15, 1964, s. 236-7.

${ }^{6}$ Maximillian Bittner, "Henry Jehlitschka, Türkische Conversations- Grammatik, von- österr.-ungar. Vice-Consul, früher Docent an der k. u. k. lischen Akademie in Wien. Mit einem Anhang von Schrifttafeln türkischer Cursivschrift nebst Anleitung. Heidelberg, Julius Verlag. 1895. Mit Schlüssel 1897 (Methode Gaspey-Otto-Sauer)”, Wiener Zeitschrift Für Die Kunde Des Morgenlandes, Volume: 13, 1899, 265-276 Retrieved from http://www.jstor.org/stable/23863573
} 
$11^{\text {th }}$ Lesson (pp. 106-116): Verbs, gerunds and infinitives, the imperative, causative, passivity, reflexivity, cooperative function, overlapping voice suffixes, compound verbs.

$12^{\text {th }}$ Lesson (pp. 116-123): Denominal verbs and voices of those verbs, auxiliary verbs.

$13^{\text {th }}$ Lesson (pp. 123-129): The use of gerunds with suffixes and prepositions, the imperative.

$14^{\text {th }}$ Lesson (pp. 129-137): Time in verbs, continuous tense.

$15^{\text {th }}$ Lesson (pp. 137-145): Present tense.

$16^{\text {th }}$ Lesson (pp. 146-154): Past definite and past indefinite.

$17^{\text {th }}$ Lesson (pp. 154-161): Future tense.

$18^{\text {th }}$ Lesson (pp. 161-168): Subjunctive modal.

$19^{\text {th }}$ Lesson (pp. 168-175): Optative and necessitative modal.

$20^{\text {th }}$ Lesson (pp. 176-186): Participles.

$21^{\text {st }}$ Lesson (pp. 186-198): The use of ol- verb.

$22^{\text {nd }}$ Lesson (pp. 198-206): Participles, complementary verb.

$23^{\text {rd }}$ Lesson (pp. 206-215): Gerundiums.

$24^{\text {th }}$ Lesson (pp. 215-222): Nouns and adjectives derived from verbs.

$25^{\text {th }}$ Lesson (pp. 222-230): Adverbs.

$26^{\text {th }}$ Lesson (pp. 230-236): Conjunctions and exclamations.

Appendix I (pp. 236-240): Some compound verbs.

Appendix II (pp. 240-244): Proverbs.

Second Chapter General Introduction (pp. 245-247): The place of Arabic and Persian in Turkish, vowel points.

$1^{\text {st }}$ Lesson (pp. 247-252): Articles in Arabic, şemsi and kameri letters.

$2^{\text {nd }}$ Lesson (pp. 252-255): Gender and determinative cases in Arabic.

$3^{\text {rd }}$ Lesson (pp. 255-259): Persian plurality and Arabic duality and plurality.

$4^{\text {th }}$ Lesson (pp. 259-269): Arabic irregular plurality.

$5^{\text {th }}$ Lesson (pp. 269-274): The use of Arabic plurality in Turkish.

$6^{\text {th }}$ Lesson (pp. 274-281): izafet (noun phrase) in Persian.

$7^{\text {th }}$ Lesson (pp. 281-287): Noun generation in Arabic.

$8^{\text {th }}$ Lesson (pp. 288-292): Correlation in Arabic.

$9^{\text {th }}$ Lesson (pp. 292-300): Verb in Arabic.

$10^{\text {th }}$ Lesson (pp. 300-306): The use of Arabic verbs in Turkish.

$11^{\text {th }}$ Lesson (pp. 307-310): Arabic noun phrases.

$12^{\text {th }}$ Lesson (pp. 311-314): Compounds derived with Persian noun phrase.

$13^{\text {th }}$ Lesson (pp. 315-320): Noun generation in Persian.

$14^{\text {th }}$ Lesson (pp. 320-326): Suffixes, verbs, and adjectives in Persian.

$15^{\text {th }}$ Lesson (pp. 326-331): Persian compound words.

$16^{\text {th }}$ Lesson (pp. 331-335): Numbers in Arabic and Persian.

$17^{\text {th }}$ Lesson (pp. 335-339): Adverbs in Arabic and Persian.

$18^{\text {th }}$ Lesson (pp. 339-343): Pronouns in Arabic and Persian.

$19^{\text {th }}$ Lesson (pp. 343-349): Prepositions in Arabic.

$20^{\text {th }}$ Lesson (pp. 349-355): Prepositions in Persian.

Conjugation Table (pp. 355-359) 
Topic Index (pp. 359-364)

Appendix 1 (pp. 365-372): Introduction of naskh and riqa scripts and writing examples.

Appendix 2 (pp. 373-394): Translation of German texts in pages 1-10 of the first chapter into Turkish in riqa script.

Appendix 3 (pp. 395-420): Various correspondences and letters.

When the content of the first volume is examined, it is obvious that the first section is in Turkish while the second section includes Arabic and Persian elements. This decision to divide the book into two sections which are not common in grammar books written by foreigners and the Turkish is the reflection of the notion put forward by the author in the preface stating that the spoken language consists Turkish dominance whereas the written language is dominated by Arabic and Persian components. Therefore, it can be depicted that Jehlitschka cared about not only teaching grammar but also facilitating the communicative skills of his target audience, which suggests an accordance with the name of the book. Another noteworthy feature in the book is the differentiation between stylistics and syntax in the order of grammar topics. Topics under the stylistics and syntax were presented in a certain order and organization. Dictionary sections in each lesson can be categorized in the context of vocabulary. In addition, it is peculiar that topics related to phonetics were only presented in the introduction without special emphasis rather than a separate section. This decision can be regarded as a reflection of the general preference towards morphologic spelling in Ottoman Turkish, not the choice of the author.

In the 123-page-long second volume named Schlüssel, Jehlitschka presented translations of Turkish and German texts presented in the first volume in pages 1-74, some information about official correspondences in pages 75-87, and Latin transcriptions of riqa letter correspondence examples at the end of the first volume and their German translations in pages 88-123. In this section, types of correspondence, military and civil ranks, titles and addressing, Arabic months, and conclusions for correspondences were demonstrated.

In the einleitung part of the first chapter, the author provided information about the historical development of Turkish, its language family, and the features of Turkish of the day. As the next step, he presented the alphabet in tabulated form in which each letter is demonstrated in the form it takes in the beginning, middle and end of the word, and their corresponding ebced and voices. In the following, mentioning riqa, diwani and taliq scripts, the author presented conjoining and non-conjoining letters, the reasoning of their ebced values, vowels and consonants, then made explanations for each letter and vowel point, gave examples for identically and differently written words. Subsequently, he placed parts that were referred as lektion. In each lesson under this title, he presented sub-sections categorized as "vokabeln", "übung”, “übersetzung”, and "konversations-mükaleme" respectively following the explanations about grammar related to each lesson. However, there is no konversationsmükaleme part exclusively in the first lesson. German corresponding of each Turkish word given as examples in lessons' explanation parts were provided with explanations. In "vokabeln" part following the explanations, additional Turkish words with Arabic letters and their German translations were presented. The indication that the words as Arabic or Persian was made by using "a." and "p." while Turkish words were not indicated with any symbols. In Übung parts that took place throughout 23 lektion, a text was placed that included the vocabulary in the vokabeln and Turkish sentences with Arabic letters. It is noteworthy that the author starts with vocabulary teaching, gradually moving up to phrase and sentential teaching. In this part, in addition to attempting to increase student's Turkish reading comprehension and Turkish to German translation achievements, the book aims to increase student's German to Turkish translation achievement with the German text presented in "Übersetzung" part. Texts are generally observed to be in accordance with grammar topics provided in related lektion. Translations of the texts in these two parts into other languages are present in Schlüssel. Starting with the $2^{\text {nd }}$ Lesson, parts including dialogues using Turkish with Arabic letters under the title of 
konversations-mükaleme were added as an addition to lektion, vokabeln, übung, and überstzung parts. In these parts, the page is divided into two columns in a way that the right column contains questions while the left column provided answers. Similarly, their translations were left out for the Schlüssel. Übung and übersetzung parts and the texts in mükaleme were relatively shorter in the beginning only to get much longer as the lessons progressed.

It can be noticed that the author was careful with the frequency of words in presenting them in vokabeln and übung parts. In the first lessons, animal names, frequently-used adjectives, "What is it? This is..." template sentences, geographical names, colors, building names, basic dialogue sentences, asking for the time, numbers, time words, fruits, shopping, and surroundings were presented as content while as the lessons progressed, in addition to these contents, words related to different countries, military, mines, trade, history, and emotions were provided. Although all the words provided within a part were not observed to form a meaning family, 3-5 worded little meaning clusters can be located within each part. For instance, words presented in the vokabeln part of the $1^{\text {st }}$ Lesson were as follows: Weather, city, village, hometown, mountain, sea, tree, stone, bird, thing, big, small, high, low, deep, cold, hot, black, white, far, close, this, that, very, what. On the other hand, words presented in the $7^{\text {th }}$ Lesson were: Apparel, my appearance, coincidence, India, stable, rooftop, drawer, stool, bed, pillow, blanket, chest, weapon, battle, siege, conquest, castle, gun, dagger, mansion, customhouse, yet, legation, costs, continuum, expected, genuine, lie, thin, bright, likable, acceptable, obedience, fardh, name, debate, levelling, article, protection, causes/reasons, precautions, acceptance, peace, force, enough, possible, and dress. While words in the noun category were given till the $10^{\text {th }}$ lektion in vokabeln and übung parts, beginning with $11^{\text {th }}$ lektion, words in verb type were provided, which is quite appropriate in terms of the order of grammar topics the book followed. Following the verb-dominant lessons, gerunds were introduced with a careful consideration for balance.

In the $23^{\text {rd }}$ Lesson, a lesestück part comprised of compound sentences was introduced along with übung part, and in $23^{\text {rd }}, 24^{\text {th }}$, and $25^{\text {th }}$ Lessons, the presence of only lesestück part is noteworthy. With the advent of this part, it can be noticed that the author moves on from sentence to paragraph, even to text level. Three out of four text in this section even has titles as follows: Difference of Men from Animals, Plants, and Golden Watch. It was mentioned in the book that these texts were extracted and taken from Muallim Naci's first reading book. However, the first to texts which were from the recitations of Talim-i Kiraat revised by Muallim Naci were partially shortened and altered before putting them in the book. For instance, in the sentence "Men are innately very different from many other animals.", the verb of the sentence "to be different" was changed into a verb that gives a meaning of "sublime and high" (âli-dir). In addition, the sentence "Men possess sight, hearing, smell, tasting and touching to experience how something feels with limbs of the body." was changed to be "Men possess sight, hearing, touching with limbs of the body, tasting, and smell.”.

After the $26^{\text {th }}$ lektion, two additional parts named anhang took place. These anhangs were prepared as dictionaries in a way that the first anhang contained German meanings of compound verbs with gel-, çık-, ver- whereas the second anhang provided German translations of some proverbs.

This part has a few attention-drawing points. As the author mentioned at the beginning of the first lesestück, an article published in Mecmua-i Fünun in 1866 was provided as a reading exercise. The author, who ensured that the text can be comprehended owing to the dictionary provided in vokabeln, stated that answering the reading comprehension questions given in German after the texts in Turkish could be more beneficial. This text that the author used as an authentic reading material was a part of the article series published by Mehmet Şevki in 
Mecmua-i Fünun in pages $212-220$ of the $41^{\text {st }}$ issue and in pages $254-260$ of the $42^{\text {nd }}$ issue. ${ }^{7}$ In spite of no information available as to why the author chose this text in any sources, it can be speculated that Japan's growth at that time and Ertugrul disaster might have had an impact on the choice. ${ }^{8}$ In the text, many subjects related to Japan ranging from its name etymology to issues such as its geography, climate, agriculture, population, language, government, religion, ruler, economy, and law order were introduced. The author took the text to his book by making some alterations just as he did to the text that he borrowed from Talim-i Kuraat.

After 20 lessons, the verb sev- was conjugated in all tenses and persons while the voice suffixes were conjugated in their single and imbricative forms. In addition, the states of the verb in which gerundial suffixes were added were shown separately. Following this section, the author presented a well-detailed and useful content table to make references to the grammar topic that took place in the corresponding lektion.

In appendix parts that succeeded, the author introduced riqa and naskh scripts to exhibit the alphabet of riqa letter and conjoining cases by providing examples of letter conjoining unique to riqa script. Moreover, the second part of the appendices offered a challenging reading exercise by presenting Turkish translations of German texts from the pages of 1-10 in the first chapter in the form of riqa script. Finally, the third appendix provided various correspondences and letter examples. Regarding the examples, it can be noticed that the correspondences are comprised of telegrams, recommendation letters, congratulation and greeting cards, invitations, letter of thanks, apology, deeds, contracts, proxy statement, certificates, and application letters. The main objective of the book was to develop Turkish grammar; however, Arabic and Persian grammars were greatly focused on to support Turkish. Furthermore, the fact that the grammar was accompanied by daily conversation texts indicates that the book aimed to develop speaking skills, as well. In connection, as can be acknowledged, the title of the book explicitly implies a focus on both areas. Even though it was not the book's direct objective, it is inevitable to assume that it improved the reading skill. In addition, despite the lack of information about the methodology concerning writing skill, the correspondence examples at the end of the book served to the purpose of facilitating writing skill. Regarding this, it can be comprehended that the author essentially focused on communication. Thus, this coincided with the goals of his target audience.

Considering the information, texts and writing examples in the book, the target audience of the book were presumably the students in the Orientalische Akademie. On top of this, the author had been working as a teacher at the said institution during the times when the books were published. Additionally, the book appears to be appropriate for the people who would be deployed to work in Ottoman regions. After all, the author himself would be working in a similar duty in Ottoman regions for a long time.

\section{Conclusion}

In the aftermath of the investigation, it was deduced that Türkische KonversationsGrammatik book written by Heinrich Jehlitschka had peculiar features. The most noteworthy property of the book is that it presented Ottoman Turkish grammar in two groups which included Turkish and Arabic-Persian elements separately. This property is the product of the sensibility of the author promoting the difference between written and spoken languages in Ottoman Turkish. Since the author noticed that spoken language mostly consisted of Turkish elements while written language included Arabic and Persian components, he specifically

\footnotetext{
7 Mehmed Şevki "Caponya Memleketi”, Мecmua-i Fünun, Volume:41 Şaban 1283, s. 212-220 http://isamveri.org/pdfosm/D00822/1283_41/1283_41_SEVKIM2.pdf; Mehmed Şevki "Caponya Memleketi”, $\begin{array}{lllll}\text { местиа-i Fünun, } & \text { Volume:42 } & \text { Ramazan } & \text { 1283, } & \text { s. }\end{array}$ http://isamveri.org/pdfosm/D00822/1283_42/1283_42_SEVKIM.pdf.

${ }^{8}$ For details, see Gülcan Yeşilöz, ibid.
} 
wanted to emphasize that in his book. With this regard, the book can be attributed with a main focus on grammar-based teaching. The second prominent feature of the book is that it used texts with both Arabic and Latin letters to enable students to become more prominent in translating and learning pronunciation. This suggests that it aimed to support students' reading and speaking skills as well as grammar. Dialogue texts in the book are noteworthy in a way that they promoted conversational speaking skill. In this context, it is peculiar that Jehlitschka attempted to embed elements of Turkish culture in the book. Moreover, the official correspondence texts should be appreciated as a preparation for civil servants who would be deployed to work in the Ottoman provinces. The author adopted the method that he referred as Gaspey-Otto-Sauer Method, which projects grammar-translation features as well as developing reading, speaking, and writing skills. The book implemented a deductive method for teaching grammar.

\section{Bibliography}

Agstner, Rudolf, Handbuch des k.k. / k.u.k. Konsulardienstes Die Konsulate der Donaumonarchie vom 18. Jh. Bis 1918, Aus dem Nachlass herausgegebenen von Gerhard Gonsa, New Academic Press, Wien 2018.

Akay Dinç, Özlem, "Polonya Kralı Poniatowski’nin Diplomasi Reformu Çerçevesinde İstanbul Şarkiyat Mektebi”, Toplumsal Tarih, Volume: 247, 2014, pp. 86-92.

Bittner, Maximillian, "Henry Jehlitschka, Türkische Conversations- Grammatik, von- österr.ungar. Vice-Consul, früher Docent an der k. u. k. lischen Akademie in Wien. Mit einem Anhang von Schrifttafeln türkischer Cursivschrift nebst Anleitung. Heidelberg, Julius Verlag. 1895. Mit Schlüssel 1897 (Methode Gaspey-Otto-Sauer)”, Wiener Zeitschrift Für Die Kunde Des Morgenlandes, Volume:13, 1899, pp. 265-276 Retrieved from http://www.jstor.org/stable/23863573.

Cengiz, Semran, "Alman Kaynaklarında Yeni Türk Edebiyat1, Otto Hachtmann ve 'Die Türkische Literatur des Zwanzigsten Jahrhunderts' Adlı Eseri”, Türkbilig/Türkoloji Araştırmaları Dergisi, Volume: 11(19), 2010, pp. 96-103.

Cengiz, Semran, "Alman Şarkiyatçı Paul Horn ve Geschichte der Türkischen Moderne (Yeni Türk Edebiyatı Tarihi) Adlı Eseri”, Turkish Studies, Volume: 5(2), 2010, pp. 1448-1454.

Doğan, Güner, "Venedik Şark Dil Okulu”, Toplumsal Tarih, Volume: 247, 2014, pp. 58-63.

Doğan, Süheyla, XIX. Yüzyılda Batı'da Yabancılara Türkçe Öğretimi Çalışmaları - W. B. Barker Örneği. Unpublished Master's Thesis, Firat Üniversitesi, Elâzı 2011.

Engelbert Deusch, Die effektiven Konsuln Österreich (-Ungars) von 1825-1918 Ihre Ausbildung, Arbeitsverhältnisse und biografien, Böhlau, Wien 2017, https://www.oapen.org/download?type=document\&docid=645108.

Eren, İsmail, "Türkiye Türkçesine Dair Rusça Neşriyat (1176-1963) Üzerinde Bibliyografya Denemesi”, Türkiyat Mecmuası, Volume: 15, 1964, pp. 236-7.

Ersoylu, Halil, “Türk Dili Üzerine Yazılmış İngilizce Gramerler”, Türk Dünyası Araştırmaları, Volume: 10, 1981, pp. 114-142.

Gezer, Ömer, "Viyana Şark Dilleri Akademisi”, Toplumsal Tarih, Volume: 247, 2014, pp. 6472.

Herzog, Christoph, "Almanca Konuşulan Ülkelerde Türkiyat ve Şarkiyat Çalışmalarının Gelişimi Üzerine Notlar" trans. Faruk Yaslıçimen, Türkiye Araştırmaları Literatür Dergisi, Volume: 15, 2010, pp. 77-148.

Hitzel, Frédérich, Dil Oğlanları ve Tercümanlar, Yapı Kredi Yayınları, İstanbul 1995. 
Mehmed Şevki “Caponya Memleketi”, Mecmua-i Fünun, Volume: 41 (Şaban 1283), pp. 212220 http://isamveri.org/pdfosm/D00822/1283_41/1283_41_SEVKIM2.pdf;

Mehmed Şevki “Caponya Memleketi”, Мecmua-i Fünun, Volume:42 (Ramazan 1283), pp. 254260 http://isamveri.org/pdfosm/D00822/1283_42/1283_42_SEVKIM.pdf.

Topuzkanamış, Ersoy, 1915'te İstanbul Alman Okulunda Yabancılara Türkçe Öğretimi: Türkisches Lesebuch Für Deutsche Kitabı, I. Kaşgarlı Mahmud Yabancı Dil Olarak Türkçe Öğretimi Sempozyumu, Erciyes Üniversitesi Kaşgarlı Mahmud Türkçe Öğretim Araştırma-Uygulama Merkezi, 03-05 Mayıs 2018, Kayseri.

Topuzkanamış, Ersoy, Almanya'da 1. Dünya Savaşı'nda Alman Askerlerine Türkçe Öğretimi: Türkisch Für Offiziere Und Mannschaften Adlı Kitap, Uluslararası Türk Kültürü ve Medeniyeti Kongresi 05-08 Eylül 2018, Balıkesir.

Ünver, Şerife, “Alman Askerlerine Türkçeyi Öğretme ve Türkiye'yi Tanıtma Amaciyla Yazılan Bir Kitabın İncelenmesi”, Milli Folklor, Volume: 25, 2013, pp. 189-201.

Yeşilöz, Gülcan, Die Übungstexte in der türkischen Konversationsgrammatik von $H$. Jehlitschka, Diplomarbeit, Universität Wien, Wien 2013. 